\title{
THE SOURCES OF ISLAND ARCS AS INDICATED BY Nd AND Sr ISOTOPIC STUDIES
}

\author{
D. J. DePaolo and G. J. Wasserburg
}

The Lunatic Asylum, Div. of Geological and Planetary Sciences, California Institute of Technology, Pasadena, California 91125

\begin{abstract}
Island arc lavas from New Britain and the Marianas have ${ }^{143} \mathrm{Nd} /{ }^{144} \mathrm{Nd}$ similar to other oceanic basalts and distinctly different from continental flood basalts and thus appear to be derived from a high $\mathrm{Sm} / \mathrm{Nd}$, light-REE-depleted reservoir. Consideration of both $\mathrm{Nd}$ and $\mathrm{Sr}$ isotopes suggests seawater involvement in the generation of some island arc lavas and thus indicates that they may be derived from altered subducted oceanic crust. Other island arc lavas show no evidence of seawater involvement and may be derived from mantle reservoirs with affinities to the sources of ocean island basalts. Andesite and rhyolite from an Andean volcano reflect assimilation of old continental crust. Nd and $\mathrm{Sr}$ in basaltic and ultrapotassic continental rocks indicate that some mafic magmas in continental regions may be derived from old low-Sm/Nd reservoirs or are heavily contaminated with old continental crustal material. Fish debris from the ocean floor provides an estimate of ${ }^{143} \mathrm{Nd} /{ }^{144} \mathrm{Nd}$ in seawater and indicates that light-REE in the marine environment are derived mainly from contments. Basalts erupted above sea level in oceanic and continental areas are isotopically distinct from those erupted on the ocean floor, suggesting a relationship between parental reservoirs and hydrostatic head.
\end{abstract}

This paper presents $\mathrm{Nd}$ and $\mathrm{Sr}$ isotopic data on lavas from oceanic island arcs which were obtained to (1) characterize the source of island arc magmas, (2) determine if these magmas are derived from mantle reservoirs which may be associated with either the sources of oceanic basalts or the sources of continental basalts, and (3) relate these observations to the role of island arcs in the growth of continental crust.

DePaolo and Wasserburg [1976a,b] (referred to as DPW, $1976 \mathrm{a}, \mathrm{b})$ showed that continental flood basalts are derived from reservoirs which have approximately chondritic $\mathrm{Sm} / \mathrm{Nd}$ ratios. Mid-ocean ridge (MOR) tholeiitic basalts appear to be derived from ancient reservoirs ( $>1 \mathrm{AE}$ old) which are distinct from those of the continental basalts and characterized by higher Sm/Nd [see also Richard, Shimizu and Allegre, 1976]. Basalts from oceanic islands have ${ }^{143} \mathrm{Nd} /{ }^{144} \mathrm{Nd}$ intermediate between MOR basalts and continental flood basalts and may represent a third type of reservoir from which basalts are derived. O'Nions, Hamilton and Evensen [1977] expanded the data on ocean island basalts and confirmed that they form a coherent group based on ${ }^{143} \mathrm{Nd} /{ }^{144} \mathrm{Nd}$. DPW [1976a,c] and O'Nions et al. [1977a] also showed that for young volcanic rocks with ${ }^{87} \mathrm{Sr} /{ }^{86} \mathrm{Sr}$ less than 0.705 there is a strong correlation between initial ${ }^{143} \mathrm{Nd} / /^{144} \mathrm{Nd}$ and ${ }^{87} \mathrm{Sr} /{ }^{86} \mathrm{Sr}$.

We have measured samples of basalt, andesite and dacite from two oceanic volcanic arcs to compare their $\mathrm{Nd}$ and $\mathrm{Sr}$ isotopic compositions with continental and other oceanic volcanic rocks. Nd isotope data provides a means of evaluating the sources of island arc magmas which is not sensitive to seawater contamination which has complicated interpretation of Sr isotope data [cf. Meijer, 1976]. We have concentrated primarily on rocks from volcanic arcs built upon oceanic crust to avoid problems of crustal contamination. In particular, the Marianas Arc is far from possible interferences from continental material. New Britain is the only arc segment built upon oceanic crust which contains the entire range of magma compositions from basalt to rhyolite, and has been extensively studied by Johnson [1976]. Samples from a volcano in the Andes of South America, a province which has been associated with the addition of island arc materials to continents, have been included in order to compare possible arc materials in the continental margin environment. A sample of gabbro from a major linear batholith belt, which may have formed in a setting

Copyright 1977 by the American Geophysical Union. similar to an island arc, is also included. Fish bone detritus has been measured to estimate ${ }^{143} \mathrm{Nd} /{ }^{144} \mathrm{Nd}$ in present day ocean water. In addition analyses of continental basic lavas confirm the existence of samples with initial $143 \mathrm{Nd} / 1^{144} \mathrm{Nd}$ far displaced from the CHUR evolution curve.

Samples. Island arc samples analyzed are listed in Table 1. All of the island arc samples appear extremely fresh in thin section and show no evidence of having been affected by post-crystallization alteration. KAS- 2 is a Karroo basalt from the Stormberg series in South Africa while PEA-3 is a Karroo basalt from Mozambique. PEA-3 was measured by DPW [1976b] but its age assignment was considered uncertain. A total K-Ar age on this sample of 103 m.y., obtained through the courtesy of S. P. Smith, confirms that it is a Karroo basalt.

Data Representation. Analytical procedures are described by DPW [1976a] and Papanastassiou, DePaolo and Wasserburg [1977]. Nd and Sr data are given in Table 1. Nd isotopic data are expressed using notation modified from DPW [1976a]. Initial ${ }^{143} \mathrm{Nd} /{ }^{144} \mathrm{Nd}$ are given as fractional deviations in parts $10^{4}\left(\epsilon_{\mathrm{Nd}}\right)$ from the value in a Chondritic Uniform Reservoir (CHUR) and are given by:

$$
\epsilon_{\mathrm{Nd}}(\mathrm{T}) \equiv \epsilon_{\mathrm{I} \mathrm{Nd}}^{\mathrm{CHUR}}(\mathrm{T}) \equiv\left[\mathrm{I}_{\mathrm{S}}(\mathrm{T}) / \mathrm{I}_{\mathrm{CHUR}}(\mathrm{T})-1\right] \times 10^{4}
$$

For simplicity in notation we introduce $\epsilon_{\mathrm{Nd}}$ to represent the deviations of initial $\mathrm{Nd}$ from the CHUR reference. $\mathrm{I}_{S}(\mathrm{~T})$ is the initial ${ }^{143} \mathrm{Nd} /{ }^{144} \mathrm{Nd}$ of a sample (S), $\mathrm{T}$ is the age of the sample, $I_{\text {CHUR }}(T)=I_{C H U R}(O)-\left({ }^{147} \mathrm{Sm} /{ }^{144} \mathrm{Nd}\right){ }_{\mathrm{CHUR}}^{\mathrm{O}_{\mathrm{R}}}\left[\mathrm{e}^{\lambda_{\mathrm{Sm}} \mathrm{T}}-1\right]$, $\mathrm{I}_{\mathrm{CHUR}}(\mathrm{O})=0.511836$ is ${ }^{143} \mathrm{Nd} /{ }^{144} \mathrm{Nd}$ in CHUR today, $\left({ }^{147} \mathrm{Sm} / 1{ }^{144} \mathrm{Nd}\right)_{\mathrm{CHUR}}=0.1936$, and $\lambda_{\mathrm{Sm}}=6.54 \times 10^{-12} \mathrm{yr}^{-1}$.

Initial ${ }^{87} \mathrm{Sr} /{ }^{86} \mathrm{Sr}$ are expressed as $\epsilon_{\mathrm{Sr}}$, defined in a manner analogous to $\epsilon_{\mathrm{Nd}}$. We define

$$
\epsilon_{\mathrm{Sr}}(\mathrm{T}) \equiv \epsilon_{\mathrm{I} \mathrm{Sr}}^{\mathrm{UR}}(\mathrm{T}) \equiv\left[\mathrm{I}_{\mathrm{S}}(\mathrm{T}) / \mathrm{I}_{\mathrm{UR}}(\mathrm{T})-1\right] \times 10^{4}
$$

$\epsilon_{\mathrm{Sr}}(\mathrm{T})$ is the deviation of initial ${ }^{87} \mathrm{Sr} /{ }^{86} \mathrm{Sr}$ in a sample from the value in a standard uniform reservoir UR at time $T$. $I_{S}(T)$ is the initial ${ }^{87} \mathrm{Sr} /{ }^{86} \mathrm{Sr}$ of the sample, $\mathrm{T}$ is the sample's age, $\left.\mathrm{I}_{\mathrm{UR}}(\mathrm{T})=\mathrm{I}_{\mathrm{UR}}(\mathrm{O})--^{87} \mathrm{Rb} /{ }^{86} \mathrm{Sr}\right)_{\mathrm{UR}}\left[\mathrm{e}^{\lambda_{R \mathrm{~b} \mathrm{~T}}}-1\right], \mathrm{I}_{\mathrm{UR}}(\mathrm{O})=$ $0.7045,\left({ }^{8} 7 \mathrm{Rb} /{ }^{86} \mathrm{Sr}\right)_{\mathrm{UR}}=0.0839$ and $\lambda_{\mathrm{Rb}}=1.39 \times 10^{-11}$
$\mathrm{yr}^{-1}$. We introduce this notation for $\mathrm{Rb}-\mathrm{Sr}$ because it allows comparison of $\mathrm{Nd}$ and $\mathrm{Sr}$ in a similar manner for rocks of arbitrary age and simplifies comparison of initial ${ }^{87} \mathrm{Sr} /{ }^{66} \mathrm{Sr}$ in rocks of greatly different ages by subtracting the effects of "normal" growth of ${ }^{87} \mathrm{Sr} /{ }^{86} \mathrm{Sr}$ with time.

$I_{U R}(O)$ is taken to be 0.7045 so that the Nd-Sr correlation line of DPW [1976b] passes through the point $\epsilon_{\mathrm{Nd}}=0, \epsilon_{\mathrm{Sr}}=$ $\mathrm{O}$. The reference reservoirs proposed here for $\mathrm{Nd}$ and $\mathrm{Sr}$ are thought to be close approximations to bulk earth values [DPW, $1976 \mathrm{~b}$ ]. However, we are avoiding incorporating this inference into the notation because we presently prefer to regard the values in the bulk earth as still to be firmly established.

The isotopic data on young basalts which provide a basis for the interpretation of island arc data are shown in Figures 1 and 2. Figure 1 shows that $\epsilon_{\mathrm{Nd}}$ values for young basalts fall into three fairly well-defined groups. Figure 2 shows data on basalts which have been analyzed for both ${ }^{87} \mathrm{Sr} /{ }^{86} \mathrm{Sr}$ and ${ }^{143} \mathrm{Nd} /{ }^{144} \mathrm{Nd}$. As first pointed out by DPW [1976c] and in more detail by DPW [1976b] and O'Nions et al. [1977] initial $\mathrm{Nd}$ and $\mathrm{Sr}$ in young basalts are strongly correlated for samples with $\epsilon_{\mathrm{Sr}}$ less than $\sim+10$. The correlation holds for basalts from both oceanic and continental regions and appears to be a fundamental property of basalt magma sources.

Results: Island Arcs. Nd isotopic data on the island arc samples are shown in Figure 1. All samples have $\epsilon_{\mathrm{Nd}}$ lying in 
the narrow range of +6.8 to +9.4 . These values are distinct from the bulk of continental flood basalts but overlap the lower range of MOR basalts and the upper range of acean island basalts. The data clearly show that these island arc rocks have not been derived from à CHUR reservoir $\left(\epsilon_{\mathrm{Nd}}=\mathrm{O}\right)$, but rather have been derived from a high-Sm/Nd (light-REEdepleted) reservoir with distinct affinities to the MOR basalts and ocean island basalts.

The $\mathrm{Nd}$ and $\mathrm{Sr}$ isotopic data for the island arc samples are showh in Figure 3. Of nine samples analyzed five basalts and basaltic andesites lie close to the correlation line. The dâcite samples from New Britain and basalt from Guam lie slightly to the right of the correlation line and the dacite from Saipan lies far to the right. Thius, although $\epsilon_{\mathrm{Nd}}$ for all samples is similar, there is a large range of $\epsilon_{\mathrm{Sr}}$. The samples which are most displaced from the correlation trend also have $\epsilon_{\mathrm{Nd}}$ most similar to MOR bdsalts. Their positions on this graph strongly suggest the involvement of seawater.

The effects of seawater contamination on the $\mathrm{Nd}$ and $\mathrm{Sr}$ isotopic composition is shown in Figure 3. No change of ${ }^{143} \mathrm{Nd} /{ }^{14} \mathrm{Nd}$ will result due to the low abundance of $\mathrm{Nd}$ in ocean water while ${ }^{87} \mathrm{Sr} /{ }^{86} \mathrm{Sr}$ will increase in the rock. Isotopic equilibration of one gram of MOR tholeiite $(100 \mathrm{ppm} \mathrm{Sr}, 10$ ppm Nd) with 10 grams of seawater $\left(6 \mathrm{ppm} \mathrm{Sr}, 3 \times 10^{-5} \mathrm{ppm}\right.$ Nd) could change $\epsilon_{\mathrm{Sr}}$ of the rock from -30 to +5 but change $\epsilon_{\mathrm{Nd}}$ by only -0.0006 . Thus if the higher $\epsilon_{\mathrm{Sr}}$ values of island arc rocks are the result of their being melted from subducted oceanic lithosphere which had $\epsilon_{\mathrm{Nd}}$ and $\epsilon_{\mathrm{Sr}}$ on the correlation line and then exchanged with seawater, then they should cover a region on Figure 3 extending to the right of the correlation line but with $\epsilon_{\mathrm{Nd}}$ identical to that of the descending slab. Such a trend would be easily distinguishable from the correlation line and would be a clear indication of a special mode of origin for these rocks. If the island arc samples were to fall along the cotrelation line, which we infer to describe the isotopic compositions of normal mantle magma sources, then we would interpret this as indicating that they are derived from mantle reservoirs similar to those from which most basalts are derived. It is also possible that subducted lithosphere with chemical and isotopic characteristics similar to the mantle reservoirs coild be the source of these lavas. The isotopic composition of uncontaminated subducted oceanic crust is probably similar to MOR basalts, but will depend on the proportions of ocean island basalt and sediment it contains. The island basalts generally have Nd concentrations about 5 to 10 times higher than MOR basalts. Therefore, if oceànic crust were comprised of $90 \%$ MOR basalt $\left(\epsilon_{\mathrm{Nd}}=+10\right)$ and $10 \%$ ocean island basalt $\left(\epsilon_{\mathrm{Nd}}=+6\right)$ it would have a bulk $\epsilon_{\mathrm{Nd}} \approx+8$, lower than most MOR basalts, but still on the correlation trend. The effect of a sediment component in the subducted oceanic crust is more difficult to assess. A mixture of $1 \%$ sediment $\left(\epsilon_{\mathrm{Nd}}=-10(?)\right.$, $30 \mathrm{ppm} \mathrm{Nd;} \epsilon_{\mathrm{Sr}}=+200,150 \mathrm{ppm} \mathrm{Sr}$ ) and $99 \%$ MOR basalt would have $\epsilon_{\mathrm{Nd}}$ different from MOR basalt by -0.6 and $\epsilon_{\mathrm{Sr}}$ different by +3 . For small $(2-5 \%)$ additions of sediment, the resulting isotopic composition of the subducted crust could still fall within the range of the basalt data which define the correlation trend. In addition, the composition of the oceanic crust could be displaced from that of MOR basalts even if sediments and ocean island basalts wère voluntrically insignificant $t_{\text {in }}$ the downgoing slab. For example, the oceanic crust being subducted beneath the Marianas is Jurassic in age. If the parent reservoir of the MOR basalts has a very high $\mathrm{Sm} / \mathrm{Nd}$ (e.g., $40 \%$ higher than chondritic), then MOR basalts erupted in Jurassic times would have had $\epsilon_{\mathrm{Nd}} \approx+8.5$ rather than +10 for the modern basalts. This value would be retained while the basalts moved from the ridge to the subduction zone since the MOR basalts have $\mathrm{Sm} / \mathrm{Nd}$ approximately equal to chondritic. , Some scatter about the $\epsilon_{\mathrm{Sr}}-\epsilon_{\mathrm{Nd}}$ cortelation line exists which is not presently understood. Therefore in addressing the problem of seawater contamination only samples which deviate substantially from this trend can be considered anomalous. Seawater contamination could conceivably occur in the island arc volcanic pile during magma ascent rather than in the oceanic crust prior to subduction. However, if this were the case, we might also expect it to occur in intraplate oceanic island volcanic piles and result in the production there of lavas with isotopic compositions displaced from the correlation line. Substantial evidence for this has not yet been found.

The samples which lie distinctly off the correlation trend, when projected back to the correlation line to remove the effects of seawater, fall well within the field of MOR basalts. This is consistent with their being derived in major part from subducted MOR basalts with (uncontaminated) isotopic compositions similar to modern ridge basalts. Those samples which lie near the correlation line have projected compositions which are somewhat displaced from the MOR basalts in the direction of the ocean island basalts. These lavas could be derived from subducted lithosphere only if it contains a significant amount

Table 1: Nd and Sr Evolutionary Parameters

\begin{tabular}{|c|c|c|c|c|c|c|c|}
\hline & Age (AE) & $\mathrm{Nd}(\mathrm{ppm})$ & ${ }^{147} \mathrm{Sm} /{ }^{144} \mathrm{Nd}$ & $\mathrm{Sr}(\mathrm{ppm})$ & ${ }^{87} \mathrm{Rb} /{ }^{86} \mathrm{St}$ & $\epsilon_{\mathrm{Nd}}{ }^{\mathrm{a}}$ & $\epsilon_{\mathrm{Sr}}{ }^{\mathrm{a}}$ \\
\hline \multicolumn{8}{|l|}{ I. Island Arcs: New Britain } \\
\hline BMR-1 (Bas. andesite, Sulu Range) & 0 & 1.76 & 0.222 & - & - & $+7.7 \pm 0.4$ & $-18.6 \pm 1.6$ \\
\hline BMR-3 (Dacite, Welcker Volcano) & 0 & - & - & - & - & $+7.8 \pm 0.5$ & $-13.5 \pm 1.3$ \\
\hline BMR-5 (Dacite, Garove Is.) & 0 & - & & - & - & $+8.3 \pm 0.5$ & $-15.0 \pm 0.7$ \\
\hline \multicolumn{8}{|l|}{ Marianas } \\
\hline MAR-1 (Basalt, Agrigan Is.) & 0 & 11.1 & 0.126 & 352 & 0.098 & $+7.9 \pm 0.6$ & $-18.6 \pm 0.9$ \\
\hline MAR-2 (Andesite, Sarigan Is.) & 0 & 12.0 & 0.166 & 352 & 0.121 & $+6.8 \pm 0.5$ & $-19.0 \pm 1.1$ \\
\hline MAR-4 (Basalt, Agrigan Is.) & 0 & 11.7 & 0.157 & 401 & 0.152 & $+7.2 \pm 0.5$ & $-18.9 \pm 0.5$ \\
\hline MAR-6 (Dacite, Saipan Is.) & 0.05 & 5.01 & 0.128 & 94 & 0.099 & $+9.1 \pm 0.5$ & $-1.5 \pm 1.0$ \\
\hline GU-4 (Basalt, Guam Is.) & 0.05 & 5.68 & 0.176 & 130 & 0.260 & $+9.4 \pm 0.5$ & $-13.1 \pm 1.1$ \\
\hline GU-7 (Basalt, Guam Is.) & 0.05 & - & - & - & - & $+8.4 \pm 0.4$ & $-21.0 \pm 1.1$ \\
\hline \multicolumn{8}{|l|}{ II. Continental } \\
\hline KAS-2 (Basalt, Karroo, S. Africa) & 0.15 & - & - & - & - & $+0.3 \pm 0.6$ & $+7.0 \pm 1.5$ \\
\hline PEA-3 (Basalt, Karroo, Mozambique) & 0.10 & 44.8 & 0.117 & 230 & 1.56 & $-18.6 \pm 1.6$ & $+312.0 \pm 4.0$ \\
\hline SMG-1 (San Marcos Gabbro, S. Cal.) & 0.12 & 4.95 & 0.153 & 455 & 0.0274 & $+4.7 \pm 0.6$ & $-14.7 \pm 0.7$ \\
\hline LH-1 (Wyomingite, Leucite Hills, Wy.) & 0.05 & $130.8^{\mathrm{b}}$ & $0.076^{b}$ & $2700^{c}$ & $0.49 \mathrm{c}$ & $-13.5 \pm 1.0$ & $+12.6 \pm 0.7$ \\
\hline PER-1 (Andesite, El Misti, Peru) & 0 & 28.1 & 0.098 & 1098 & 0.127 & $-8.9 \pm 0.5$ & - \\
\hline PER-2 (Rhyolite, El Misti, Peru) & 0 & 21.7 & 0.091 & 444 & 0.463 & $-12.7 \pm 0.1$ & $+64.3 \pm 1.3$ \\
\hline DOS-1 (Fish Debris, Pacific Ocean) & 0 & - & - & - & - & $-9.2 \pm 0.7$ & - \\
\hline CHUR & all $\mathrm{T}$ & - & 0.1936 & - & - & 0 & - \\
\hline UR & all $\mathrm{T}$ & - & - & - & 0.0839 & - & 0 \\
\hline
\end{tabular}

${ }^{a}$ Initial values; calculated from measured values and known ages; uncertainties $20 .{ }^{b}$ Kay and Gast (1973). ${ }^{\mathrm{c}}$ Carmichael (1967). 


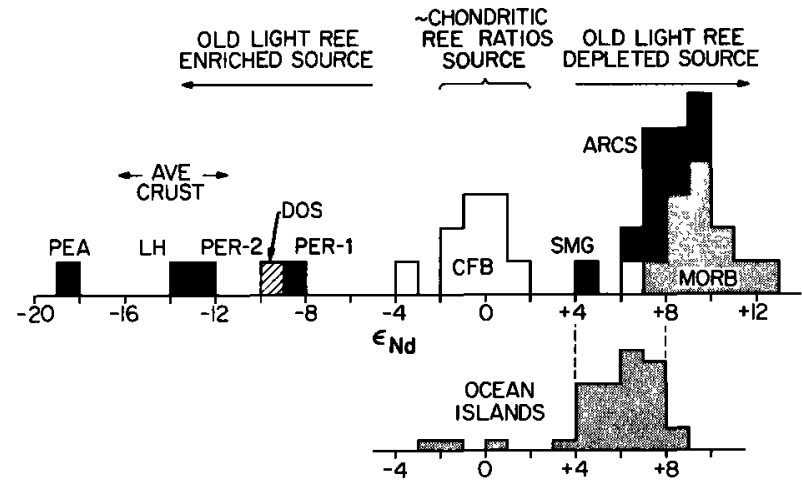

Fig. 1: Histogram of $\epsilon_{\mathrm{Nd}}$ of three groups of young basalts (unshaded and lightly shaded) and in samples measured in this study (solid and ruled) with inferred REE pattern of parent reservoirs. Data on continental flood basalts (CFB), mid-ocean ridge basalts (MORB) and ocean island basalts from DePaolo and Wasserburg [1976a,b,], O'Nions et al., [1977], and Richard et al. [1976] .

of ocean island basalt or sediment or if it has an isotopic composition somewhat different from modern MOR basalt. Rather than call on the presence of sediment or ocean island basalt in the subducted slab to explain only the samples which show no evidence of seawater involvement, we consider it most likely that those samples with isotopic compositions on the correlation trend have been derived from mantle reservoirs with affinities to the sources of ocean island basalts and contain little or no slab-derived component.

In summary, our preferred interpretation of all the data is that island arc lavas are comprised of a component derived from a mantle reservoir similar in isotopic composition to ocean island basalts and a component derived from subducted MOR basalt. Silicic lavas may contain a larger slab-derived component than more mafic lavas. These conclusions are consistent with those outlined by DePaolo and Wasserburg [1977], and O'Nions, Evensen, and Carter [1977b].

Meijer [1976] measured $\mathrm{Pb}$ and $\mathrm{Sr}$ isotopes in rocks from the Mariana Island arc and concluded that island arc lavas were melted in part from altered subducted oceanic crust and not from mantle reservoirs similar to ocean island basalt sources. Although his data suggest melting of the slab, it is difficult to consider them as strong evidence against derivation from an ocean island type mantle reservoir, especially since the $\mathrm{Pb}$ data from Hawaii [Tatsumoto, 1966] are similar to island arc samples.

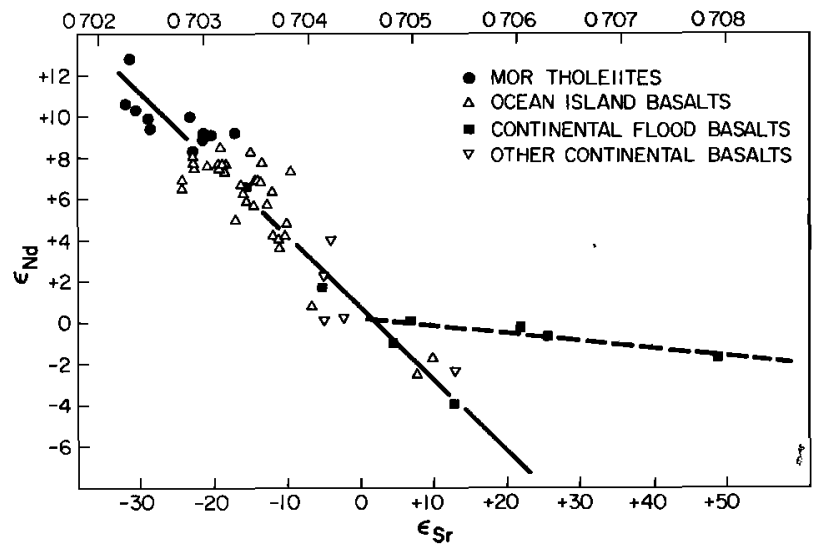

Fig. 2: $\epsilon_{\mathrm{Nd}}$ versus $\epsilon_{\mathrm{Sr}}$ for young oceanic and continental basalts showing strong correlation trend for samples with $\epsilon_{\mathrm{Sr}}<0$ and a trend of different slope defined by some continental flood basalts with $\epsilon_{\mathrm{Sr}}>0$. Data are from DePaolo and Wasserburg [1976a,b], O'Nions et al. [1977], Richard et al. [1976] and DePaolo and Wasserburg [unpublished] .
Continental Rocks. Nd data on continental rocks are shown in Figure 1. In contrast to the oceanic rocks, samples PER-1 and PER-2 have large negative $\epsilon_{\mathrm{Nd}}$, which suggest that they were formed by melting or assimilation of old continental crustal material with low Sm/Nd. This is not surprising since the central Andes are underlain by an extremely thick crust (up to 70 kilometers). These data provide the first strong indication that crustal anatexis may be an important process in some continental margin volcanic arcs. This interpretation is in disagreement with that of Brooks, James and Hart [1976] -who suggested that these lavas were derived from special mantle reservoirs. Sample PEA-3, a Karroo lava, has a large negative $\epsilon_{\mathrm{Nd}}$ and extremely high $\epsilon_{\mathrm{Sr}}$. These characteristics are expected in very old upper continental crustal material and suggest that this magma was massively contaminated with crustal $\mathrm{Nd}$ and $\mathrm{Sr}$ at shallow levels in the crust. Sample KAS-1 (Table 1) and SWB-1A [DPW, 1976b], however, indicate that this is not typical of the Karroo lavas, most of which have $\epsilon_{\mathrm{Nd}} \approx 0$. Sample LH-1, a rare ultrapotassic lava has a large negative $\epsilon_{\mathrm{Nd}}$ but in contra-distinction to PEA-3, it has $\epsilon_{\mathrm{ST}}$ near zero. This lava appears to be derived from a special reservoir which is old $(>1 \mathrm{AE}$ ) and has low $\mathrm{Sm} / \mathrm{Nd}$ and low $\mathrm{Rb} / \mathrm{Sr}$. Such a reservoir could possibly be found in the lower crust, which may be depleted in Rb and $\mathrm{U}$ [Heier, 1965; Zartman and Wasserburg, 1969 ], or in the mantle. Sample SMG-1 is from a major linear batholith belt and therefore could have originated in a tectonic setting similar to an island arc [c.f. Dickinson, 1970]. Its $\epsilon_{\mathrm{Nd}}$ and $\epsilon_{\mathrm{S} r}$ fall within the field of ocean island basalts and very near the correlation line. This sample could be representative of a major addition of new crust which has $\epsilon_{\mathrm{Nd}}$ different from zero.

Fish Debris - Seawater. Sample DOS-1 has $\epsilon_{\mathrm{Nd}}=-9.2$ and thus lies far below the CHUR evolution curve (Figure 1). Fish debris is a scavenger of heavy metals in seawater during slow dissolution on the deep ocean floor [Arrhenius, Bramlette, and Piccioto, 1957] and may give an estimate of $\epsilon_{\mathrm{Nd}}$ of seawater. The $\epsilon_{\mathrm{Nd}}$ of this sample is similar to that of average North American shale [DPW, 1976a] which may be representative of REE in the continental crust [Haskin et al., 1966] and is far displaced from the values found in oceanic volcanic rocks. If average crustal material has $\epsilon_{\mathrm{Nd}} \approx-14$ and average oceanic volcanics have $\epsilon_{\mathrm{Nd}} \approx+8$, then about $75 \%$ of the Nd in authigenic phases on the ocean floors is derived from continental sources and $25 \%$ is from oceanic regions.

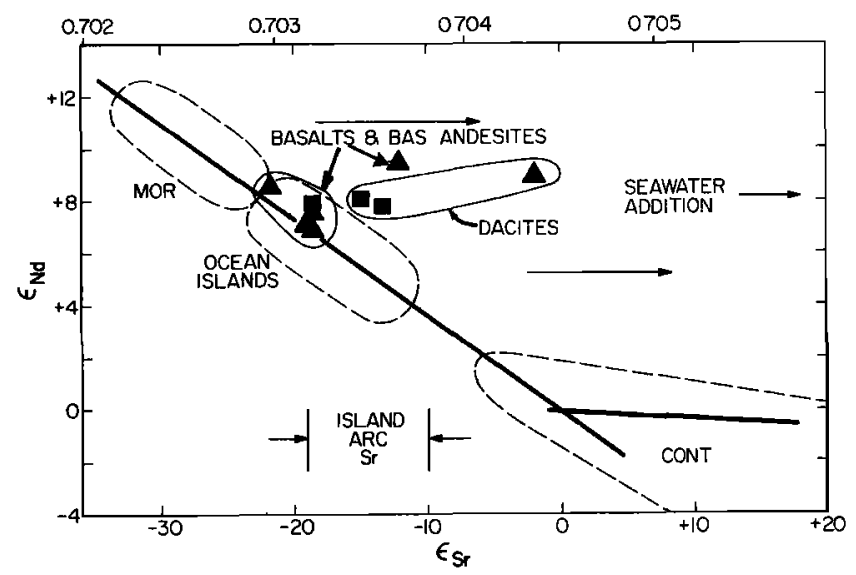

Fig. 3: $\epsilon_{\mathrm{Nd}}$ and $\epsilon_{\mathrm{Sr}}$ for island arc samples. Arrows indicate effect of seawater contamination. Approximate fields of MOR, ocean island and continental (CONT) basalts from Fig. 2 shown for comparison. Triangles represent Marianas samples and squares are New Britain samples. The typical range of $\epsilon_{\mathrm{Sr}}$ for oceanic island arcs taken from the literature is also shown. ${ }^{87} \mathrm{Sr} /{ }^{86} \mathrm{Sr}$ ratios indicated at the top apply only at $\mathrm{T}=0$. Uncertainties are slightly larger than the symbols. 
Discussion: Continental growth. The bulk composition and REE abundances of island arcs and continental margin volcanics arcs closely approximate the composition of average continental crust [Taylor and White, 1965]. This observation together with the fact that island arcs are usually found at or near continental margins has lead to the hypothesis that they are the site of production of new continental crust. Continents thus may grow through time by accreting at their margins material produced in island arcs. If this is the case, then the measurements made in this study indicate that new continental material has a $\mathrm{Nd}$ isotopic composition similar to oceanic basalts and should not lie on the CHUR curve.

DPW [1976a,b] noted that if undifferentiated mantle had chondritic $\mathrm{Sm} / \mathrm{Nd}$, the $\epsilon_{\mathrm{Nd}}$ of oceanic basalts were consistent with their being derived from mantle material which had been left as residue from ancient partial melting events. Trace element and $\mathrm{Sr}$ isotope ratios in MOR basalts had previously led to this hypotheses [Gast, 1968]. These ancient melting events could have contributed to building of the continental crust. Since island arc rocks have $\epsilon_{\mathrm{Nd}}$ similar to the oceanic volcanics, they may also be derived from such residual material. Thus if island arcs represent the typical materials being added to form new continental crust, then it must be concluded that continental crust is now being derived from depleted mantle reservoirs which were previously tapped to form continental crust in earlier epochs of crust-building. Since these reservoirs may be more depleted in "crustal components" today than in the past, new continental material derived from them may have a significantly different average composition than Archean crust. This problem is fundamentally related to the $\mathrm{Sm} / \mathrm{Nd}$ and $\mathrm{Rb} / \mathrm{Sr}$ values for the bulk earth.

Oceanic Topography and Magma Sources. Basalts erupted on the ocean floor have $\epsilon_{\mathrm{Nd}}=+8$ to +12 and distinctive trace element chemistry while those erupted above sea level on continents, oceanic islands, and island arcs have $\epsilon_{\mathrm{Nd}}<+8$. Such isotopic differences must be attributed to the lithic reservoirs in the mantle from which the magmas were melted. Thus there is a correlation between the isotopic characteristics of the lithic reservoir from which a magma is derived and the elevation at which that magma is erupted. From hydrostatic considerations the height of a volcano is proportional to the depth to the base of the magma column. This hydrostatic consideration and the isotopic data suggest a direct link between the depth of the chamber from which a magma is erupted and the associated mantle lithic reservoir from which the magma is derived. This suggests that ocean floor basalts could be derived from a layer close to the surface (Layer A; $\epsilon_{\mathrm{Nd}}>+8$ ) whereas oceanic island basalts and continental basalts are derived from deeper levels (Layers B, C, etc; $\epsilon_{\mathrm{Nd}}<+8$ ). Such a simple model would explain why basalts isotopically identical to MOR basalts are almost never found on continents or oceanic islands, and would imply that the major isotopic and chemical zonation in the mantle may be a planetary scale stratification. Layer A could be so shallow as to be nonexistent under continents, where its level would be occupied by the continental mass itself.

Acknowledgements: We are grateful to $R$. W. Johnson of the Australian Bureau of Mineral Resources for providing carefully selected samples from New Britain and comments on the manuscript. R. J. Stem and F. Barker kindly provided samples from the Marianas, some of which are currently under petrochemical study. We thank I. S. E. Carmichael for petrologic fireside chats and arousing our interest in alkaline lavas with funny names. W. G. Melson provided the Andean samples. We also thank G. Goles for samples of Karroo lavas. Special thanks go to G. Arrhenius who gave us his old teeth. This work has been supported by NSF Grant EAR 76-22494 and NASA Grant NGL 05-002188.

Division Contribution No. 2948

\section{References}

Arrhenius, G., M. N. Bramlette and E. Piccioto, Localization of radioactive and stable heavy nuclides in ocean sediments, Nature 180 , 85-86, 1957.

Brooks, C., D. E. James and S. R. Hart, Ancient lithosphere: Its role in young continental volcanism, Science 193, 1086-1094, 1976.

Carmichael, l., The mineralogy and petrology of the volcanic rocks from the Leucite Hills, Wyoming, Contr. Mineral. and Petrol. 15 24-66, 1967.

DePaolo, D. J. and G. J. Wasserburg, Nd isotopic variations and petrogenetic models, Geophys. Res. Lett. 3, 249-252, 1976a.

DePaolo, D. J. and G. J. Wasserburg, Inferences about magma sources and mantle structure from variations of ${ }^{143} \mathrm{Nd} /{ }^{144} \mathrm{Nd}$, Geophys. Res. Lett. 3, 743-746, 1976b.

DePaolo, D. J. and G. J. Wasserburg, Variation of ${ }^{143} \mathrm{Nd} /{ }^{144} \mathrm{Nd}$ in continental and oceanic igneous rocks and chemical zonation of the mantle (abs.) Geol. Soc. Am. Abs. 8, 835, 1976c.

DePaolo, D. J. and G. J. Wasserburg, Nd in Island Arc and continental volcanic rocks (abs.), EOS $58,1977$.

Dickinson, W. R., Relations of andesites, granites and derivative sandstones to arc-trench tectonics, Rev. Geophys. Space Phys. 8, 813-860, 1970.

Gast, P. W., Trace element fractionation and the origin of tholeiitic and alkaline magma types, Geochim. Cosmochim. Acta 32, 1057-1086, 1968.

Haskin, L. A., T. R. Wildeman, F. A. Frey, K. A. Collins, C. R. Keedy and M. A. Haskin, Rare earths in sediments, J. Geophys. Res. 71, 6091-6105, 1966.

Heier, K. S., Metamorphism and the chemical differentiation of the crust, Geol. Fören. Stockh Förh. 87, 249-256, 1965.

Johnson, R. W., Potassium variations across the New Britain volcanic arc, Earth. Plan. Sci. Lett. 31, 184-191, 1976.

Kay, R. W. and P. W. Gast, The rare-earth content and origin of alkali-rich basalts $J$. Geol., 81, 653-682, 1973

Meijer, $\mathrm{A}$., $\mathrm{Pb}$ and $\mathrm{Sr}$. isotopic data bearing on the origin of volcanic rocks from the Mariana island-arc system, Geol. Soc. Am. Bull. 87, 1358-1369, 1976.

O'Nions, R. K., P. J. Hamilton and N. M. Evensen, Variations in ${ }^{143} \mathrm{Nd} /{ }^{144} \mathrm{Nd}$ and ${ }^{87} \mathrm{Sr} /{ }^{86} \mathrm{Sr}$ ratios in oceanic basalts, Earth Planet Sci. Lett. 34, 13-22, 1977a.

O'Nions, R. K., N. M. Evensen, P. J. Hamilton and S. R. Carter, Nd- and Sr- isotope compositions of altered oceanic crust and island arc tholeiites (abs.), EOS 58, 1977b.

Papanastassiou, D. A., D. J. DePaolo and G. J. Wasserburg, Rb-Sr and Sm-Nd chronology and genealogy of basalts from the Sea of Tranquility, Proc. Lunar Sci. Conf. 8th (in press), 1977.

Richard, P., N. Shimizu and C. J. Allegre, ${ }^{143} \mathrm{Nd} /{ }^{146} \mathrm{Nd}$, a natural tracer An application to oceanic basalts, Earth Planet. Sci. Lett. 31, 269-278 1976.

Tatsumoto, M., Isotopic composition of lead in volcanic rocks from Hawaii, Iwo Jima and Japan, J. Geophys. Res. 7I, 1721-1723, 1966.

Taylor, S. R. and A. J. R. White, Geochemistry of andesites and the growth of continents, Nature 205, 271-273, 1965.

Zartman, R. E. and G. J. Wasserburg, The isotopic composition of lead in potassium feldspars from some 1.0 b.y. old North American igneous rocks, Geochim. Cosmochim. Acta. 33, 901-942, 1969.

(Recelved July 25, 1977;

revised August 23, 1977;

accepted September 6, 1977.) 